\title{
Gender Motivation Differences of Czech and Chinese Employees
}

\author{
Lenka Ližbetinová1*, Miloš Hitka² \\ 1 Department of Humanities, Faculty of Corporate Strategy, Institute of Technology and Business, \\ Okružní 517/10, 37001 České Budějovice, Czech Republic \\ 2 Department of Business Economics, Faculty of Wood Sciences and Technology, Technical University in Zvolen, \\ T. G. Masaryka 24, 96053 Zvolen, Slovak Republic \\ * Corresponding author, e-mail: lizbetinova.lenka@gmail.com
}

Received: 16 July 2018, Accepted: 29 May 2019, Published online: 28 November 2019

\begin{abstract}
The aim of the article is to identify significant differences in motivational preferences of employees of Small and Medium-sized Enterprises (SMEs) by comparing their membership to the region and gender. The paper presents the partial outcomes of research on the level of motivation and the preferences of employees in the Czech Republic and the Beijing municipality administration of the People's Republic of China. The survey was carried out in 2017 using a questionnaire. The questionnaires were distributed in small and medium-sized enterprises engaged in various areas of business. The sample included the entire territory of the Czech Republic (CR) and the Beijing municipality administration in the People's Republic of China (PRC). A total of 2,673 respondents participated in the survey, of which 899 were respondents in the Beijing municipality administration and 1,774 respondents from the Czech Republic. Descriptive statistics was used to characterize the sampling unit. The other methods used to evaluate data in the article were the Student two-sample t-test, F test, and ANOVA. The differences in motivational preferences of employees revealed by the study can be used as a basis for creating appropriate incentive programs for multinational business teams.
\end{abstract}

Keywords

small and medium enterprises, motivational preferences, motivation, employees of the Czech Republic, employees of the People's Republic of China

\section{Introduction}

Global competition is an essential element in defining business strategies in the world (Čambál and Cagáňová, 2010; Ďuračík et al., 2017; Grencikova et al., 2016; Tokarčíková and Kucharčíková, 2015; Zaborova et al., 2017). Managers are aware of the international competitiveness of the environment and are looking for ways to successfully operate on the market (Cambal et al., 2012; Koraus et al., 2018; Lorincová and Potkány, 2016). This effort is mostly focused on human resource management practices. In global business, human resources management is still considered as a tool that can effectively help market development and growth (Gottwald et al., 2017).

The main purpose of managing human resources is to efficiently and positively employ employees in the organization for the benefit of the organization (Fejfarová and Urbancová, 2016; Olšovská et al., 2016; Stachová et al., 2017). Thanks to a productive work environment, an

organization can achieve its goals and continue its work (Babatunde, 2015; Burma, 2014). Employee motivation is an indispensable part of human resources management (Javorčíková, 2018). Robescu and Iancu (2016) and Machová (2014) define motivation as the willingness of the individual to do something that is conditioned by activities to meet their needs. Zafar et al. (2014) described motivation as energizing individuals to behave in a certain way. According to Richman (2015), motivation is the direction and the persistence of efforts to achieve a specific goal. Eshun and Duah (2011) characterize motivation as the willingness to develop a high level of effort towards realising organizational goals, conditioned by the ability to satisfy some individual needs. Each organization seeks to achieve high performance through its workforce (Lizbetin and Bartuska, 2017; Nduka, 2016). This means that it pays great attention to how the best individuals can 
be motivated by means such as incentives, rewards and leadership positions within the organization in which they work (Coyle-Shapiro et al., 2013; Žul'ová et al., 2018).

Thus, motivation is the result of the interaction of conscious and unconscious factors, the intensity of desire or need, the stimulating or rewarding value of the goal and the expectation of the individual and his surroundings (Manzoor, 2012; Vetráková et al., 2016). These factors are the reasons why people behave in a certain way. Most employees need to feel motivated (Kubal'a and Vetráková, 2018; Kucharčíková and Mičiak, 2018). Some employees are motivated by money, while others are motivated by recognition. Motivational levels in the workplace have a direct impact on employee productivity (Mura et al., 2017; Stachová et al., 2018, Šustr et al., 2016). Employees who are motivated perform their duties better and their performance consequently increases (Chiu et al., 2002). Motivation can be classified as internal or external. The internal type of motivation is based on individual needs or interest in the task (Jigjiddorj et al., 2019). This does not include work on activities for external rewards. Instead, inner motivation requires a feeling of inner pleasure from one's own activities. It can be seen as a force that includes activities without external stimulus. According to Kucharčíková and Mičiak (2017), individuals are really motivated when they seek interest, a satisfaction of curiosity, self-interest, or a personal challenge at work. External motivation is the opposite of internal motivation. The source of external motivation comes from a particular external environment. Lorincová et al. (2016b) gives as examples of external motivation the promise of money and verbal rewards.

Men and women perform their work and build their careers differently, while education, employment, and labour choices for men and women are often limited by social standards and stereotypes (Knapcova and Kucharcikova, 2015).

Women exhibit less physical mobility (real movement between firms and industries) than men. There are many factors that can limit the physical mobility of women, including their preferred choice of profession, which often allows a greater balance between work and family at a lower salary and fewer opportunities for progress. The lack of organizational policies and cultures (which promote work-life balance) can cause women to leave their jobs after a certain period of time, thus reducing their career opportunities (Fratričová and Kirchmayer, 2018). In short, the physical mobility of women is often limited by relationships and commitments towards others. For example, women often refuse to apply for jobs or even refuse offers for jobs that would require her family's relocation, increased travel, a reduction in family time, or leaving relatives. In contrast, men may have less psychological mobility (the ability to consider a wide range of alternative careers) than women (Forret et al., 2010).

Even though higher rates of unemployment may lead to some degree of physical mobility, we expect that men and women will have differences in psychological mobility based on their gender role. This mobility will be especially affected by the presence of children, and this can aggravate the social expectations of men. Given the cost of educating children and securing their education, it is likely that many men will have greater pressures to stand out in their careers, to support their families and to fulfill the role of family life (Lorincová et al., 2016a).

Men usually have a completely different attitude to power and hierarchy than women. Working life strongly affects both sexes. For example, hierarchical systems are attractive to men and foreign to women. "Masculine" qualities, such as the ability to lead, purposefulness, and deriving enjoyment from decision-making are provided by men who take up leadership positions in the economy. Very few women have a sense of power and a hierarchy in a purely male way. Generally, women do not know how to deal with this way of thinking, especially when it comes to work and relationships. They have different goals and perspectives and want to raise children and maintain their family in peace (Nitzsche, 2005).

Recent studies (Olšovská et al., 2016; Stachová et al., 2017; Vetráková et al., 2016) confirm that men prefer hierarchical structures and typically concentrate on outcomes, while women gain satisfaction and motivation when the team prevails in a positive atmosphere.

Employers want motivated and productive employees (Bajzikova et al., 2013; Bohinská, 2018; Nedeliaková et al., 2017). Ways to increase their motivation do not necessarily rely solely on monetary stimulus. However, it is also necessary to take into account regional differences (Kohnová et al., 2019; Stachová et al., 2019) and gender differences, which may affect the level of motivation. Given the current employers' needs in Europe, the aim of the present study is to assess whether there are significant differences in the level of employee motivation in small and medium-sized enterprises in two distinct regions - the Central Europe region of the Czech Republic and the Beijing region of China. We assume that the employees of the regions 
analyzed will prefer different motivational factors in view of the different living standards in each country.

Differences in motivation preferences are also expected due to the different cultural habits described by several authors in their research. Xing et al. (2017) suggest that these differences are most visible in approaches to power and authority. In most Western societies, government is seen as a means of serving people's interests. Thus, control and balance are established as a natural result of the mandate of the people. In China, however, the power of leaders originates from their perceived virtue. A higher degree of government intervention is not a cause for concern, because Chinese should be able to trust their government.

Hofstede (2007) supports this view. The results of his research show that what he terms "power distance" is significantly stronger in China. This means that it is a society in which inequalities between people are acceptable. The relationship of a subordinate with a superior tends to be polarized, and there is no defense against the abuse of power by superiors. In a high power distance culture, subordinates are influenced by formal authority and sanctions, and they should not have ambitions beyond their position. Workers are thus highly loyal to their employer. The Czech society also accepts a hierarchical arrangement in which each individual has a place and does not need any further substantiation (Hofstede Insights, 2019). Hierarchy in an organization is seen as reflecting inherent inequalities. Centralization is popular and subordinates expect to be told what they should do. However, the power distance is significantly lower than in Chinese society.

Hofstede and McCrae (2004) argue that the most distinctive difference between these cultures is in the dimension of collectivism vs. individualism. China is characterized by a collective culture where people act in the interest of the group and suppress their interests in favour of the group. While relationships with colleagues in a group are cooperative, relationships with other groups are cool or even hostile.

By contrast, Czech society is strongly individualistic. There is a high preference for a free social framework on the basis of which individuals are expected to take care of themselves and their immediate families (Poor et al, 2018). "In Individualist societies offence causes guilt and a loss of self-esteem, the employer/employee relationship is a contract based on mutual advantage, hiring and promotion decisions are supposed to be based on merit only, management is the management of individuals" (Hofstede Insights, 2019) . Unlike the Czechs, people in collectivist cultures (such as the Chinese) tend to perceive mental health problems as personal failures and as caused by personal factors (Chen and Mak, 2008). The traditional Chinese view discourages the expression of extreme emotions that are considered to be pathogenic factors that interfere with the normal functioning of the body.

\section{Methodology}

The aim of this article is to determine significant differences in the motivational preferences of employees of Small and Medium-sized enterprises (SMEs) by comparing them in terms of their place of origin and gender. The paper presents partial outcomes of research on the level of motivation and motivation preferences of employees in the Czech Republic and the Beijing city of the People's Republic of China

A questionnaire was used to determine the level of motivation. The questionnaire consisted of closed questions, where the first part of the questionnaire looked at the socio-demographic and qualification characteristics of the employees in the compared regions. The second part of the questionnaire was based on evaluation by motivational factors which reveal information about the characteristics of the working environment, the working conditions, the type of assessment applied, and remuneration system in the company, the personnel work in the company, the social care system and the employee benefits. The survey was carried out in 2017. The sample included the entire territory of the Czech Republic (CR) and the Beijing municipality administration in the People's Republic of China (PRC). Questionnaires were distributed in small and medium-sized enterprises across a wide range of business fields.

In total, 2,673 respondents participated in the survey, of which 899 were respondents from Beijing municipality in the PRC (comprising 432 men and 467 women). In the Central Europe region, 1,774 respondents came from the Czech Republic, of which 819 were men and 955 women (Table 1).

In terms of age, there were $31.9 \%$ of employees under $30,25.1 \%$ from 31 to $40,26.8 \%$ from 41 to 50 and $16.2 \%$ over 50 in the Czech sample. In the PRC, the research sample $38.1 \%$ of the respondents were under $30,27.3 \%$ were

Table 1 The frequency of analyzed respondents

\begin{tabular}{lcccc}
\hline Gender & $\begin{array}{c}\text { The region of the PRC - } \\
\text { the Beijing municipality }\end{array}$ & $\begin{array}{c}\text { The region of the Central } \\
\text { Europe region - CR }\end{array}$ \\
\hline Male & 432 & $48 \%$ & 819 & $46 \%$ \\
Female & 467 & $52 \%$ & 955 & $54 \%$ \\
\hline Total & 899 & $100 \%$ & 1774 & $100 \%$ \\
\hline
\end{tabular}


aged between 31 and 40, $25.6 \%$ were from 41 to 50, and $9.0 \%$ were over 50 years of age.

The questionnaire was created by Hitka (2009) and focused on identifying employee motivation preferences. The questionnaire was translated by a Chinese native speaker. The distribution of the questionnaires was carried out by personal distribution in combination with the use of targeted mailing. An electronic version of the questionnaire was produced using the Google forms platform. The questionnaire examines the preferences related to 30 motivation factors. Motivational factors were analyzed in five areas:

- financial evaluation (basic salary, further financial reward, fair employee evaluation),

- social security (employee benefits, company vision, the prestige of a company name, regional development, relationship to the environment, leisure time),

- working conditions (physical effort at work, workplace safety, stability of employment, the content of the work performed, information on work performance, working time, working environment, work performance, psychological burden);

- career advancement (opportunities to apply your own abilities, career growth, empowerment and competencies, occupational prestige, individual decision making, self-realization, education and personal growth, work recognition); and

- interpersonal relations (workplace atmosphere, good working team, workplace communication, supervisor's approach).

To avoid influencing the respondents, the individual motivation factors were arranged in alphabetical order. Employees could assign one of five grades to a Likert scale, where 5 was the maximum and 1 minimum for each question. Descriptive statistics was used to characterize the sampling unit. The method of comparison was used to find the difference between the values in the sampling unit. The significance of differences of arithmetic means and standard deviations was tested at a significance level of $\alpha=$ 0.05 in order to eliminate the statement that the differences found were not caused due to the representation fault.

The statistical method through the average was used based on Eq. (1) (Schmidtová and Vacek, 2013):

$$
\bar{x}=\frac{\sum_{i=1}^{n} x_{i}}{n},
$$

where is average, $\mathrm{xi}$ is individual values, $\mathrm{n}$ is the total size of the sampling unit. Given the scale and independence of the sample, Student two-sample t-test was used, when testing the null hypothesis of equal averages of motivation factors in terms of belonging to the country. Testing the null hypothesis was performed at the significance level $\alpha=0.05$. The order of importance of motivational factors was determined using the arithmetic mean of individual motivation factors. Differences in the test quantities were evaluated by the t-test for independent selections. Assumptions of scattering were verified using the F test. The P-value, calculated by the t-test, represents the probability of the error. Consequently, we tested gender differences using ANOVA (Statistic Solutions, 2013) for the most important motivational factors. ANOVA is used to test three or more variables to see if there is a difference between them (Statistic How To, 2018). Consequently, we have defined two working hypotheses:

- H1: We assume that there are significant differences in the motivation of employees between the different regions.

- H2: We anticipate that there are significant differences between men in both regions and women in both regions.

- H3: We assume that there are significant regional and gender differences in motivation.

\section{Results and discussion}

We defined statistically significant differences in motivation factors between regions based on average values of importance. Table 2 presents the descriptive characteristics of the selection mean, the standard deviation and the $95 \%$ confidence interval for the base file diameter.

In both countries we can conclude that there are statistically different requirements for motivating employees to $5 \%$ materiality levels for workplace atmosphere, good working team, further financial reward, physical effort at work, job safety, workplace communication, the prestige of a company's name, of the opportunity to apply their own abilities, information on work performance, work performance, empowerment and competencies, prestige of occupational, the approach of the supervisor, scope for independent decision making, fair evaluation of the employee, work safety, psychological burden, regional development, education and personal growth, leisure time, recognition and basic salary. These results are confirmed by H1.

In the next part of the paper, the 8 most important motivational factors are compared in both regions from a gender perspective. Despite similarities in motivation requirements, there are statistically significant differences 
Table 2 Statistically significant differences in motivation levels in PRC and CR

\begin{tabular}{|c|c|c|c|c|c|c|c|c|}
\hline Motivational factors & $\begin{array}{l}\text { Mean } \\
(\text { PRC) }\end{array}$ & $\begin{array}{c}\text { Mean } \\
(\mathrm{CR})\end{array}$ & $\begin{array}{c}\text { Standard } \\
\text { deviation } \\
(\mathrm{PRC})\end{array}$ & $\begin{array}{c}\text { Standard } \\
\text { deviation } \\
\text { (CR) }\end{array}$ & $\mathrm{t}$ & $\begin{array}{l}\text { Degrees of } \\
\text { freedom }\end{array}$ & p-level & F-ratio \\
\hline Atmosphere at the workplace & 4.17 & 4.51 & 0.95 & 0.71 & -10.46 & 2671 & 0.000 & 1.79 \\
\hline Good working team & 4.19 & 4.50 & 0.96 & 0.72 & -9.36 & 2671 & 0.000 & 1.79 \\
\hline Further financial reward & 4.14 & 4.27 & 0.98 & 0.79 & -3.66 & 2671 & 0.007 & 1.53 \\
\hline Physical effort at work & 3.79 & 3.65 & 1.03 & 0.98 & 3.51 & 2671 & 0.006 & 1.10 \\
\hline Stability of employment & 3.95 & 4.40 & 0.99 & 0.79 & -12.64 & 2671 & 0.000 & 1.55 \\
\hline Communication at the workplace & 4.08 & 4.36 & 0.94 & 0.81 & -7.82 & 2671 & 0.000 & 1.36 \\
\hline Prestige / Company name & 3.90 & 3.80 & 1.04 & 1.05 & 2.28 & 2671 & 0.029 & 1.02 \\
\hline Possibility to apply your own abilities & 4.03 & 4.04 & 0.95 & 0.88 & -0.41 & 2671 & 0.025 & 1.17 \\
\hline Content of the performed work & 4.05 & 4.14 & 0.96 & 0.79 & -2.54 & 2671 & 0.691 & 1.47 \\
\hline Information on work performance & 3.94 & 3.97 & 0.99 & 0.92 & -0.68 & 2671 & 0.017 & 1.17 \\
\hline Working time & 4.00 & 4.12 & 0.95 & 0.91 & -3.23 & 2671 & 0.506 & 1.09 \\
\hline Work environment & 3.95 & 4.13 & 1.06 & 0.83 & -4.70 & 2671 & 0.001 & 1.64 \\
\hline Work performance & 4.03 & 4.08 & 0.98 & 0.81 & -1.51 & 2671 & 0.000 & 1.44 \\
\hline Career growth & 4.08 & 3.90 & 0.95 & 0.90 & 4.71 & 2671 & 0.154 & 1.10 \\
\hline Empowerment and competencies & 4.04 & 3.75 & 0.96 & 0.99 & 7.21 & 2671 & 0.000 & 1.08 \\
\hline Occupational prestige & 3.91 & 3.80 & 1.01 & 0.97 & 2.76 & 2671 & 0.000 & 1.09 \\
\hline Supervisor's approach & 4.07 & 4.47 & 0.97 & 0.78 & -11.73 & 2670 & 0.005 & 1.55 \\
\hline Individual decision making & 3.94 & 4.01 & 1.03 & 0.89 & -1.86 & 2671 & 0.000 & 1.36 \\
\hline Self-realization & 3.97 & 3.97 & 1.02 & 0.91 & 0.13 & 2671 & 0.077 & 1.26 \\
\hline Employee benefits & 3.85 & 3.93 & 1.03 & 0.92 & -2.16 & 2671 & 0.903 & 1.25 \\
\hline Fair assessment & 4.01 & 4.41 & 1.02 & 0.81 & -11.00 & 2671 & 0.037 & 1.57 \\
\hline Workplace safety & 4.05 & 4.23 & 1.04 & 0.91 & -4.54 & 2671 & 0.000 & 1.29 \\
\hline Stress / Psychological burden & 3.97 & 3.99 & 1.05 & 0.96 & -0.46 & 2671 & 0.000 & 1.20 \\
\hline Vision of the company & 3.92 & 3.74 & 1.00 & 1.04 & 4.24 & 2670 & 0.653 & 1.07 \\
\hline Contribution to regional development & 4.01 & 3.48 & 1.00 & 1.13 & 11.81 & 2670 & 0.000 & 1.27 \\
\hline Education and personal growth & 3.99 & 3.94 & 1.03 & 0.94 & 1.16 & 2670 & 0.000 & 1.22 \\
\hline Ecological approach of the company & 3.88 & 3.66 & 1.03 & 1.13 & 4.86 & 2671 & 0.263 & 1.21 \\
\hline Leisure time & 4.03 & 4.14 & 0.97 & 0.92 & -2.82 & 2671 & 0.000 & 1.11 \\
\hline Work recognition & 4.14 & 4.14 & 0.96 & 0.86 & -0.11 & 2671 & 0.004 & 1.25 \\
\hline Basic salary & 4.11 & 4.46 & 1.00 & 0.80 & -9.83 & 2671 & 0.000 & 1.53 \\
\hline
\end{tabular}

Note: Significantly important values are highlighted in bold.

between men in the region of the PRC surveyed and in the CR (Table 3). These differences are identified in the following motivational factors: workplace atmosphere, good working team, further financial reward, workplace communication, supervisor's approach, workplace safety and basic salary. This is confirmed by $\mathrm{H} 2$ in the male category.

A similarity in motivation requirements was found when the level of motivation among women in the Beijing municipality administration and in the CR was analysed. However, there are also statistically significant differences between women in the municipality of Beijing and their counterparts in the CR (Table 4). Statistically, significant differences are determined within motivational factors: workplace atmosphere, good working team, workplace communication, supervisor's approach, workplace safety and basic salary. Based on this, we confirm $\mathrm{H} 2$ for the category of women.

The dependencies of the regions compared and the average values of the male and female categories for the basic salary motivation factor were investigated using the ANOVA HSD test. The results show that men's preferences in the CR are different from men and women in the Beijing administration municipality. Also, women's preferences in the $\mathrm{CR}$ are different from men and women in the region of 
Table 3 Comparing the level of motivation among men in the PRC and the CR

\begin{tabular}{|c|c|c|c|c|c|c|c|c|}
\hline Selected motivational factors & $\begin{array}{l}\text { Mean } \\
(\mathrm{PRC})\end{array}$ & $\begin{array}{c}\text { Mean } \\
(\mathrm{CR})\end{array}$ & $\begin{array}{c}\text { Standard } \\
\text { deviation } \\
(\mathrm{PRC})\end{array}$ & $\begin{array}{l}\text { Standard } \\
\text { deviation } \\
\text { (CR) }\end{array}$ & $\mathrm{t}$ & $\begin{array}{c}\text { Degrees of } \\
\text { freedom }\end{array}$ & p-level & F-ratio \\
\hline Atmosphere at the workplace & 4.11 & 4.48 & 1.00 & 0.71 & -7.47 & 1247 & 0.000 & 1.98 \\
\hline Good working team & 4.14 & 4.46 & 0.96 & 0.76 & -6.39 & 1247 & 0.000 & 1.59 \\
\hline Further financial reward & 4.10 & 4.28 & 1.01 & 0.81 & -3.57 & 1247 & 0.009 & 1.56 \\
\hline Communication at the workplace & 4.07 & 4.25 & 0.98 & 0.84 & -3.48 & 1247 & 0.009 & 1.37 \\
\hline Content of the performed work & 4.01 & 4.11 & 0.95 & 0.83 & -1.90 & 1247 & 0.068 & 1.30 \\
\hline Supervisor's approach & 4.01 & 4.38 & 1.03 & 0.84 & -6.89 & 1246 & 0.000 & 1.50 \\
\hline Workplace safety & 3.99 & 4.17 & 1.00 & 0.97 & -2.98 & 1247 & 0.003 & 1.06 \\
\hline Basic salary & 4.02 & 4.45 & 1.05 & 0.80 & -8.17 & 1247 & 0.000 & 1.73 \\
\hline
\end{tabular}

Note: Significantly important values are highlighted in bold.

Table 4 Comparing the level of motivation among women in the PRC and the CR

\begin{tabular}{|c|c|c|c|c|c|c|c|c|}
\hline Selected motivational factors & $\begin{array}{l}\text { Women } \\
\text { (PRC) }\end{array}$ & $\begin{array}{c}\text { Women } \\
\text { (CR) }\end{array}$ & $\begin{array}{c}\text { Standard } \\
\text { deviation } \\
(\mathrm{PRC})\end{array}$ & $\begin{array}{c}\text { Standard } \\
\text { deviation } \\
(\mathrm{CR})\end{array}$ & $\mathrm{t}$ & $\begin{array}{l}\text { Degrees of } \\
\text { freedom }\end{array}$ & p-level & F-ratio \\
\hline Atmosphere at the workplace & 4.22 & 4.54 & 0.91 & 0.71 & -7.27 & 1422 & 0.000 & 1.62 \\
\hline Good working team & 4.23 & 4.53 & 0.97 & 0.68 & -6.79 & 1422 & 0.000 & 2.02 \\
\hline Further financial reward & 4.19 & 4.26 & 0.94 & 0.77 & -1.59 & 1422 & 0.138 & 1.50 \\
\hline Communication at the workplace & 4.10 & 4.44 & 0.90 & 0.77 & -7.59 & 1422 & 0.000 & 1.38 \\
\hline Content of the performed work & 4.09 & 4.17 & 0.97 & 0.76 & -1.65 & 1422 & 0.129 & 1.64 \\
\hline Supervisor's approach & 4.12 & 4.55 & 0.91 & 0.71 & -9.79 & 1422 & 0.000 & 1.62 \\
\hline Workplace safety & 4.10 & 4.28 & 1.07 & 0.85 & -3.38 & 1422 & 0.001 & 1.56 \\
\hline Basic salary & 4.19 & 4.47 & 0.94 & 0.81 & -5.72 & 1422 & 0.000 & 1.34 \\
\hline
\end{tabular}

Note: Significantly important values are highlighted in bold.

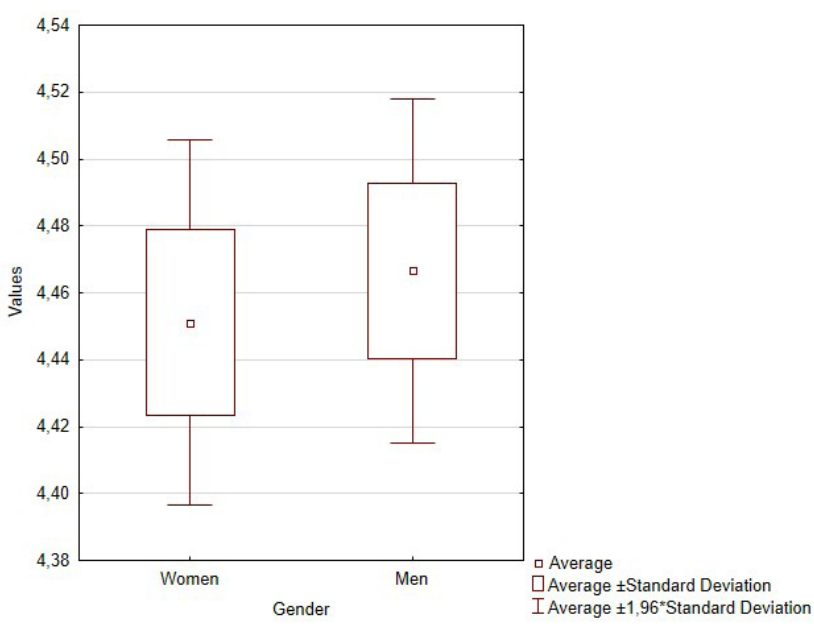

Fig. 1 Comparison of motivation factor - basic salary in CR

Beijing for the basic salary factor (Figs. 1 and 2). From a gender perspective, there is a high gender similarity in the CR and a significant gender gap in the PRC (Table 5).

Also, the statistically significant differences in the significance level of $5 \%$ between regions and gender are confirmed even in the motivational factor atmosphere at the workplace. We confirmed differences between men

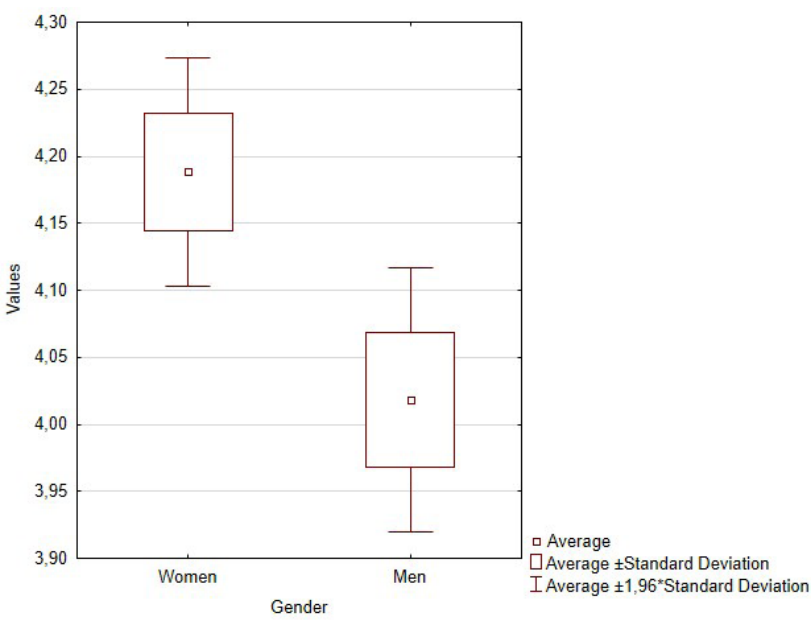

Fig. 2 Comparison of motivation factor - basic salary in PRC

and women in the CR and between men and women in the selected region of the PRC (Table 6, Figs. 3 and 4). For the motivating factor of a good working team (Figs. 5 and 6), there are also statistically significant differences between men and women in the CR compared to the region of Beijing (Table 7). Based on the results described in Tables 5, 6 and 7, the hypothesis $\mathrm{H} 3$ is confirmed. 
Table 5 Region/gender dependency for motivation factor - basic salary

\begin{tabular}{lllccc}
\hline \multirow{2}{*}{ Region } & \multirow{4}{*}{$\begin{array}{c}\text { Unspecific N HSD; The marked differences are } \\
\text { significant at the level of significance } \mathrm{p}<, 05000\end{array}$} \\
& & \multicolumn{2}{c}{$\mathrm{CR}$} & \multicolumn{2}{c}{ PRC } \\
& & $\begin{array}{c}\text { Men } \\
\mathrm{M}=4.45\end{array}$ & $\begin{array}{c}\text { Women } \\
\mathrm{M}=4.47\end{array}$ & $\begin{array}{c}\text { Men } \\
\mathrm{M}=4.02\end{array}$ & $\begin{array}{c}\text { Women } \\
\mathrm{M}=4.19\end{array}$ \\
\hline \multirow{2}{*}{$\mathrm{CR}$} & Men & & 1.000 & $\mathbf{0 . 0 0 0}$ & $\mathbf{0 . 0 0 0}$ \\
& Women & 1.000 & & 0.000 & 0.000 \\
\multirow{2}{*}{ PRC } & Men & 0.000 & 0.000 & & 0.021 \\
& women & 0.000 & 0.000 & 0.021 & \\
\hline
\end{tabular}

Note: Significantly important values are highlighted in bold.

Table 6 Region/gender dependency for motivation factor - atmosphere at the workplace

\begin{tabular}{|c|c|c|c|c|c|}
\hline \multirow{3}{*}{ Region } & \multirow{3}{*}{ Gender } & \multicolumn{4}{|c|}{$\begin{array}{l}\text { Unspecific N HSD; The marked differences are } \\
\text { significant at the level of significance } \mathrm{p}<, 05000\end{array}$} \\
\hline & & \multicolumn{2}{|c|}{$\mathrm{CR}$} & \multicolumn{2}{|c|}{ PRC } \\
\hline & & $\begin{array}{c}\text { Men } \\
\mathrm{M}=4.48\end{array}$ & $\begin{array}{l}\text { Women } \\
\mathrm{M}=4.54\end{array}$ & $\begin{array}{c}\text { Men } \\
M=4.12\end{array}$ & $\begin{array}{l}\text { Women } \\
\mathrm{M}=4.22\end{array}$ \\
\hline \multirow{2}{*}{$\mathrm{CR}$} & Men & & 0.722 & 0.000 & 0.000 \\
\hline & Women & 0.722 & & 0.000 & 0.000 \\
\hline \multirow{2}{*}{ PRC } & Men & 0.000 & 0.000 & & 0.492 \\
\hline & women & 0.000 & 0.000 & 0.492 & \\
\hline
\end{tabular}

Note: Significantly important values are highlighted in bold.

Table 7 Region/gender dependency for motivation factor - good working team

\begin{tabular}{|c|c|c|c|c|c|}
\hline \multirow{3}{*}{ Region } & \multirow{3}{*}{ Gender } & \multicolumn{4}{|c|}{$\begin{array}{l}\text { Unspecific N HSD; The marked differences are } \\
\text { significant at the level of significance } p<, 05000\end{array}$} \\
\hline & & \multicolumn{2}{|c|}{ CR } & \multicolumn{2}{|c|}{ PRC } \\
\hline & & $\begin{array}{c}\text { Men } \\
M=4.46\end{array}$ & $\begin{array}{l}\text { Women } \\
\mathrm{M}=4.53\end{array}$ & $\begin{array}{c}\text { Men } \\
M=4.15\end{array}$ & $\begin{array}{l}\text { Women } \\
\mathrm{M}=4.23\end{array}$ \\
\hline \multirow{2}{*}{$\mathrm{CR}$} & Men & & 0.346 & 0.000 & 0.000 \\
\hline & Women & 0.346 & & 0.000 & 0.000 \\
\hline \multirow{2}{*}{ PRC } & Men & 0.000 & 0.000 & & 0.492 \\
\hline & women & 0.000 & 0.000 & 0.703 & \\
\hline
\end{tabular}

Note: Significantly important values are highlighted in bold.

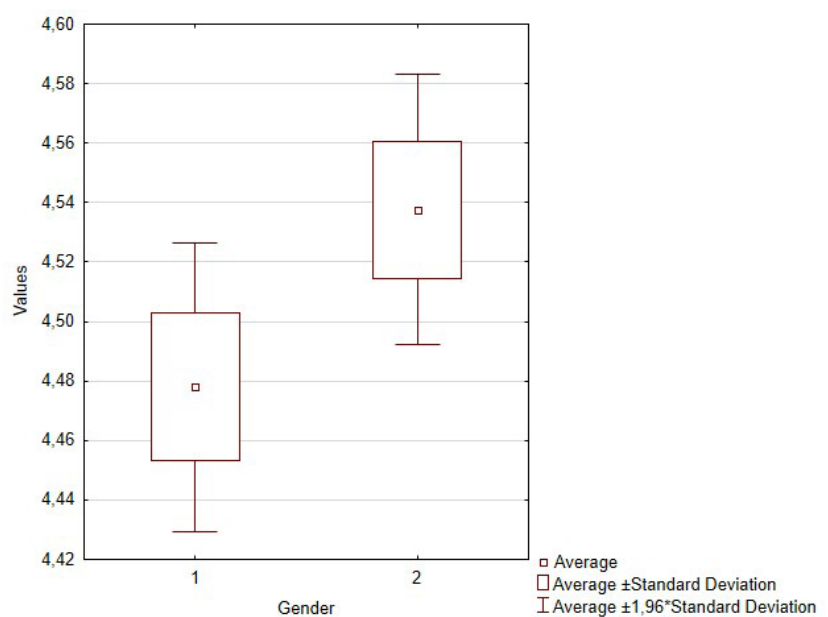

Fig. 3 Comparison of motivation factor - the atmosphere at the workplace in $\mathrm{CR}$

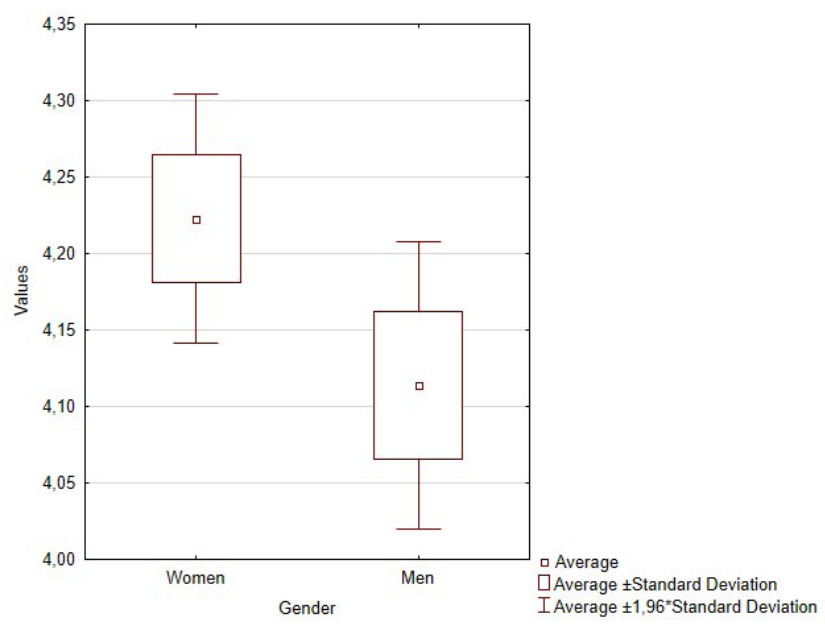

Fig. 4 Comparison of motivation factor - the atmosphere at the workplace in PRC 


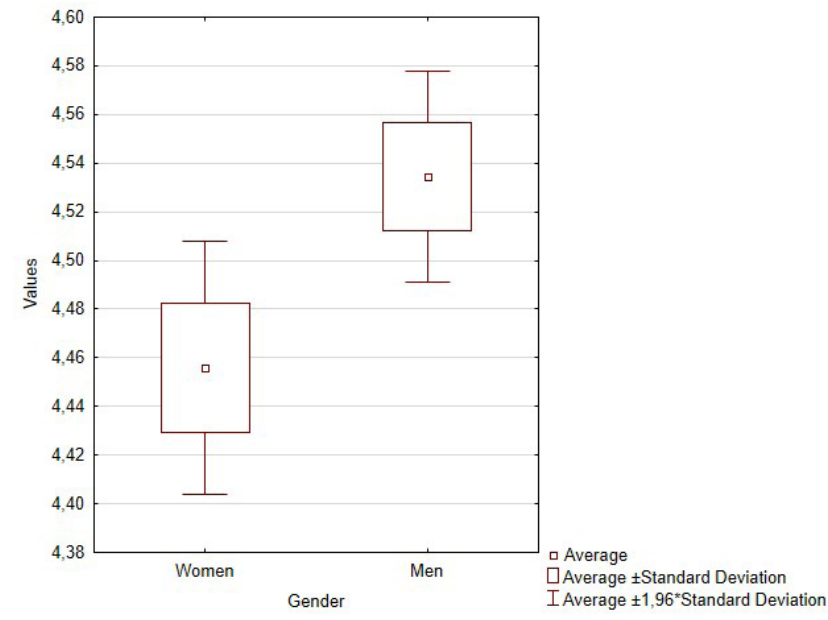

Fig. 5 Comparison of motivation factor - good working team in CR

Linhartová and Urbancová (2012) claim that men put more emphasis on the financial side of work and the opportunity to evaluate than women. They work for a salary for most of their working life, while women often work part-time to have more time for family responsibilities. Therefore, the differences between men and women in working values can be reflected in differences in motivational factors. Several studies (Lepold et al., 2018; Sánchez-Sellero et al., 2018, Kertész et al., 2017; Němec et al., 2015; Sanchez-Sellero et al., 2013; Kropivšek et al., 2010; Osabiya, 2015) have shown that men earn more than women. One possible explanation is that male values of work lead to greater productivity in a traditional work environment and the reason for higher wages may be their greater labour value.

From the comparison of the motivation factors of the countries analyzed, it can be stated that the "basic salary" motivation factor - is one of the most important factors. However, the importance of this motivating factor also varies by region and gender. There are also differences within the regions and genders. Significant regional and gender differences were found for preferences for the motivational factors "workplace atmosphere" and "good working team". Both factors are among the most important motivating factors in the CR as well as in the PRC. The results suggest that differences exist also within the regions according to gender, but they are not statistically significant.

\section{Conclusion}

Analysis of the results of our research into the level of employee motivation in the CR and the region of Beijing indicates that the motivation factors of the two regions

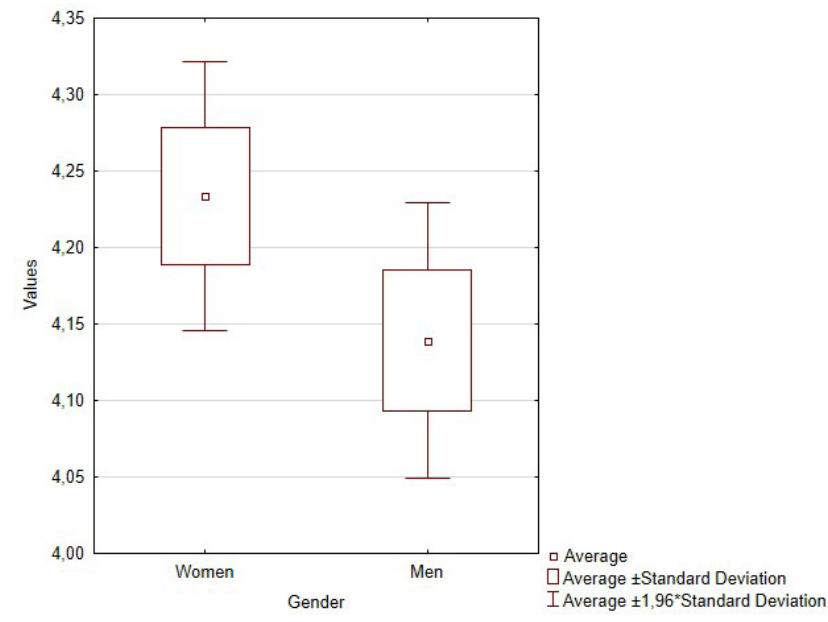

Fig. 6 Comparison of motivation factor - good working team in PRC

compared are significantly different. Employees of Czech enterprises are more demanding to reach the required level of motivation. Chinese employees are less demanding in most of the factors that Czech employees regard as key - a workplace atmosphere, a working team, a superior approach and a basic salary. The reasons can perhaps be found in the level of economic development of the two countries (Poór et al., 2018), their approach to employment of workers and the impact of the diversity of the cultures. In this case, the lower demands in terms of workplace atmosphere and a working team may be based on the level of collectivism in this culture (Hofstede, 2007). Lower demands on access to superiors, fairness of assessment, working conditions and basic salary can be explained by the higher power distance in Chinese society (Hofstede Insights, 2019). Factors involved in the formation of individual prestige are significantly more important for Chinese employees than for Czech employees. This can be explained by the Chinese concept of "face" (“mianzi”) (Smith, 2012). Face can be given (gei mianzi), gained (zengjia mianzi), or lost (diu mianzi). Therefore, it is a very important fact to maintain face (liu mianzi) because the loss of face has strong consequences for the functioning of the individual in society.

This concept has its roots in Confucianism and social harmony. "Face in Chinese Society" is a sociological expression of the desire to maintain social stability, hierarchy and respect, the need to be respected by others and not to feel embarrassed in social interactions. The factors which are most effective in gaining face for Chinese employees are: employer prestige, occupational prestige, empowerment and competencies, contribution to regional 
development and education and personal growth (Buckley et al., 2010). This facial perception determines the respect, respect, pride and dignity accorded to the individual as a result of his social success and his practice. Based on these findings, there is a clear need to develop employee access so that leadership is able to identify their needs and expectations and set up a fair system of motivation by business leaders. Since the current rate of economic development requires an ever-increasing number of staff in the European Union, it is necessary to import labour from abroad. Considering the different needs of foreign employees, as well as their gender differences, will thus be increasingly necessary from the point of view of motivation.

\section{References}

Bajzikova, L., Sajgalikova, H., Wojcak, E., Polakova, M. (2013) "Are Flexible Work Arrangements Attractive Enough for Knowledgeintensive Businesses?", Procedia - Social and Behavioral Sciences, 99, pp. 771-783.

https://doi.org/10.1016/j.sbspro.2013.10.549

Bohinská, A. (2018) "Human resource manager's responsibility in creating a culture of legal compliance and ethics in an organization", Journal of Human Resource Management, 21(2), pp. 8-15. [online] Available at: https:/www.jhrm.eu/2018/11/8-human-resource-managers-responsibility-in-creating-a-culture-of-legal-compliance-and-ethics-in-an-organization/ [Accessed: 22 October 2018]

Buckley, P. J., Clegg, J., Tan, H. (2010) "Cultural awareness in knowledge transfer to China-The role of guanxi and mianzi", In: Foreign direct investment, China and the world economy, Palgrave Macmillan, London, UK, pp. 165-191. [online] Available at: https://www.academia.edu/24108985/Cultural_awareness_in knowledge_transfer_to_China_The_role_of_guanxi_and_mianzi [Accessed: 20 June 2018]

Burma, Z. A. (2014) "Human resource management and its importance for today's organizations", International Journal of Education and Social Science, 1(2), pp. 85-94.

Čambál, M., Cagáňová, D. (2010) "Corporate Culture Influence on Effective Initialization and Application of Knowledge Management in Enterprises", In: Proceedings from the 11th European Conference on Knowledge Management, Famalicão, Portugal, pp. 176-181. [online] Available at: https://www.researchgate.net/publication/298528913_Corporate_culture_influence_ on_effective_initialization_and_application_of_knowledge management_in_enterprises [Accessed: 20 June 2018]

Čambál, M., Caganova, D., Sujanova, J. (2012) "The Industrial Enterprise Performance Increase through the Competency Model Application", In: Proceedings from the 4th European Conference on Intellectual Capital (ECIC), Helsinki, Finland, pp. 118-126. [online] Available at: https://www.researchgate.net/ publication/291832713_The_Industrial_Enterprise_Performance Increase_through_the_Competency_Model_Application [Accessed: 20 June 2018]

\section{Acknowledgments}

This research was supported by VEGA 1/0024/17 Computational model of motivation, APVV-16-0297 Updating of anthropometric database of Slovak population, TL02000559 Safe and secure cities for pedestrians and senior citizens, TL02000017 Intergenerational management to support digitization in construction and TL01000349 Stabilization and development of SMEs in rural areas.

Chiu, R. K., Luk, V. W. M., Tang, T. L. P. (2002) "Retaining and motivating employees: Compensation preferences in Hong Kong and China", Personnel Review, 31(4), pp. 402-431. https://doi.org/10.1108/00483480210430346

Coyle-Shapiro, J., Hoque, K., Kessler, I., Pepper, A., Richardson, R., Walker, L. (2013) "Human resource management", University of London, London, UK. [online] Available at: https://www.dphu.org/uploads/ attachements/books/books_5937_0.pdf [Accessed: 15 June 2018]

Ďuračík, M., Kršák, E., Hrkút, P. (2017) "Current Trends in Source Code Analysis, Plagiarism Detection, and Issues of Analysis Big Datasets", Procedia Engineering, 192, pp. 136-141. https://doi.org/10.1016/j.proeng.2017.06.024

Eshun, C., Duah, F. K. (2011) "Rewards as a Motivation Tool for Employees Performance", MSc Thesis, Blekinge Tekniska Hogskola, BTH. [online] Available at: https://www.diva-portal. org/smash/get/diva2:832968/FULLTEXT01.pdf [Accessed: 15 June 2018]

Fejfarová, M., Urbancová, H. (2016) "Human resource management in small and medium-sized enterprises in the Czech Republic", Scientific Papers of the University of Pardubice, 23(36), pp. 79-90. [online] Available at: https://dk.upce.cz/bitstream/handle/10195/64718/FejfarovaM_HumanResourceManagement_2016. pdf?sequence=1\&isAllowed=y [Accessed: 12 June 2018]

Forret, M. L., Sullivan, S. E., Mainiero, L. A. (2010) "Gender role differences in reactions to unemployment: Exploring psychological mobility and boundaryless careers", Journal of Organizational Behavior, 31(5), pp. 647-666. https://doi.org/10.1002/job.703

Fratričová, J., Kirchmayer, Z. (2018) "Barriers to work motivation of generation Z", Journal of Human Resource Management, 21(2), pp. 28-39. [online] Available at: https://www.jhrm. eu/2018/11/28-barriers-towork-motivation-of-generation-z/ [Accessed: 22 October 2018]

Gottwald, D., Svadlenka, L., Lejsková, P., Pavlisova, H. (2017) "Human capital as a tool for predicting development of transport and communications sector: The Czech Republic perspective", Communications, 19(4), pp. 50-56. [online] Available at: https://komunikacie.uniza.sk/index.php/communications/article/ view/270/242 [Accessed: 04 July 2018] 
Grencikova, A., Spankova, J., Kordos, M. (2016) "Entry of a New Generation "Millenians" on the Labor Market", In: 3rd International Multidisciplinary Scientific Conference on Social Sciences and Arts SGEM 2016, Albena, Bulgaria, pp. 861-868. https://doi.org/10.5593/SGEMSOCIAL2016/B23/S07.108

Hitka, M. (2009) "Model analýzy motivácie zamestnancov vo výrobných podnikách" (Model of employee motivation analysis in manufacturing enterprises), Technická Univerzita vo Zvolene, Zvolen, Slovakia. (in Slovak)

Hofstede Insights (2019) "Compare Countries. Geert Hofstede cultural dimensions", [online] Available at: https://www.hofstede-insights. com/product/compare-countries/ [Accessed: 18 May 2018]

Hofstede, G. (2007) "A European in Asia", Asian Journal of Social Psychology, 10(1), pp. 16-21. https://doi.org/10.1111/j.1467-839X.2006.00206.x

Hofstede, G., McCrae, R. R. (2004) "Personality and Culture Revisited: Linking Traits and Dimensions of Culture", Cross-Cultural Research, 38(1), pp. 52-88. https://doi.org/10.1177/1069397103259443

Javorčíková, J. (2017) "Motivation, engagement, and achievement in the EFL literature class: 21st-century perspectives", In: Teaching literature for the 21st century, SlovakEdu, Nitra, Slovakia, pp. 89-95.

Jigjiddorj, S., Tsogbadrakh, T., Choijil, E., Zanabazar, A. (2019) "The Mediating Effect of Employee Loyalty on the Relationship between Job Satisfaction and Organizational Performance", In: International Conference on Economics, Management and Technology in Enterprises 2019 (EMT 2019), Paris, France, pp. 197-201. https://doi.org/10.2991/emt-19.2019.37

Kertész, A., Séllei, B., Izsó, L. (2017) "Key Factors of Disabled People’s Working Motivation: An Empirical Study Based on a Hungarian Sample", Periodica Polytechnica Social and Management Sciences, 25(2), pp. 108-116. https://doi.org/10.3311/PPso.10459

Knapcova, D., Kucharcikova, A. (2015) "The Status of Women on the Regional Labour Market", In: International Scientific Conference on Knowledge for Market Use - Women in Business in the Past and Present, Olomouc, Czech Republic, pp. 517-529.

Kohnová, L., Papula, J., Salajová, N. (2019) "Internal factors supporting business and technological transformation in the context of industry 4.0", Business: Theory and Practice, 20, pp. 137-245. https://doi.org/10.3846/btp.2019.13

Korauš, A., Mazák, M., Dobrovič, J. (2018) "Quantitative analysis of the competitiveness of Benelux countries", Entrepreneurship and Sustainability Issues, 5(4), pp. 1069-1083. https://doi.org/10.9770/jesi.2018.5.4(26)

Kropivšek, J., Jelačić, D., Grošelj, P. (2011) "Motivating Employees of Slovenian and Croatian Wood-industry Companies in Times of Economic Downturn", Drvna Industrija, 62(2), pp. 97-103. https://doi.org/10.5552/drind.2011.1040

Kubala, J., Vetráková, M. (2018) "Reasons of the employees' stabilization in hotels in Slovakia", Acta Oeconomica Universitatis Selye, 6(2), pp. 90-100. [online] Available at: https://acta.ujs.sk/docs/ acta\%206_2\%20print.pdf [Accessed: 05 August 2018]

Kucharčíková, A., Mičiak, M. (2017) "Human Capital Management in Transport Enterprise", In: MATEC Web of Conferences, 134, Article number: 00030.

https://doi.org/10.1051/matecconf/201713400030
Kucharčíková, A., Mičiak, M. (2018) "Human Capital Management in Transport Enterprises with the Acceptance of Sustainable Development in the Slovak Republic", Sustainability, 10(7), Article number: 2530. https://doi.org/10.3390/su10072530

Lepold, A., Tanzer, N., Bregenzer, A., Jiménez, P. (2018) "The Efficient Measurement of Job Satisfaction: Facet-Items versus Facet Scales", International Journal of Environmental Research and Public Health, 15(7), Article number: 1362.

https://doi.org/10.3390/ijerph15071362

Linhartová, L., Urbancová, H. (2012) "Results of analysis of employee mobility: Factors affecting knowledge continuity", Acta Universitatis Agriculturae et Silviculturae Mendelianae Brunensis, 60(4), pp. 235-244. https://doi.org/10.11118/actaun201260040235

Lizbetin, J., Bartuska, L. (2017) "The Influence of Human Factor on Congestion Formation on Urban Roads", Procedia Engineering, 187, pp. 206-211. https://doi.org/10.1016/j.proeng.2017.04.366

Lorincová, S., Potkány, M. (2016) "The Proposal of Innovation Support in Small and Medium-sized Enterprises", In: Majerník, M., Daneshjo, N., Bosák, M. (eds.) Production Management and Engineering Sciences, Routledge - Taylor \& Francis, Abingdon, UK, pp. 157-161. https://doi.org/10.9774/GLEAF.9781315673790_29

Lorincová, S., Schmidtová, J., Balážová, Ž. (2016a) "Perception of the corporate culture by managers and blue-collar workers in Slovak wood-processing businesses", Acta Facultatis Xylologiae Zvolen, 58(2), pp. 149-163. https://doi.org/10.17423/afx.2016.58.2.16

Lorincová, S., Schmidtová, J., Javorčíková, J. (2016b) "Employee Job Satisfaction in Furniture Manufacturing Companies in the Slovak Republic", Drvna Industrija, 67(4), pp. 351-362. https://doi.org/10.5552/drind.2016.1614

Machová, R. (2014) "What motivates a human?", Acta Oeconomica, 3(2), pp. 88-101. [online] Available at: https://acta.ujs.sk/docs/6/absztraktok\%206.docx [Accessed: 21 June 2018]

Manzoor, Q. A. (2012) "Impact of Employees Motivation on Organizational Effectiveness", European Juornal of Business and Management, 3(3), pp. 36-45. [online] Available at: https:// pdfs.semanticscholar.org/0298/2685b0bac41fab976f729a292db221134cdb.pdf [Accessed: 01 June 2018]

Mura, L., Ključnikov, A., Tvaronavičienè, M., Androniceanu, A. (2017) "Development Trends in Human Resource Management in Small and Medium Enterprises in the Visegrad Group", Acta Polytechnica Hungarica, 14(7), pp. 105-122. https://doi.org/10.12700/APH.14.7.2017.7.7

Nduka, O. (2016) "Employee motivation and performance", MSc Thesis, Centria University of Applied Sciences. [online] Available at: https://www.coursehero.com/file/25167159/ Employee20motivation20and20performancepdf/ [Accessed: 22 June 2018]

Nedeliaková, E., Panák, M., Šipuš, D. (2017) "Innovative Trends in Process-Oriented Quality Management within Railway Transport", Periodica Polytechnica Transportation Engineering, 45(2), pp. 84-89.

https://doi.org/10.3311/PPtr.9582 
Němec, F., Potkány, M., Lorincová, S., Raušer, D. (2015) "A Proposal for the Optimization of Storage Areas in a Selected Enterprise", Naše More, 62(3), pp. 101-108. https://doi.org/10.17818/NM/2015/SI3

Nitzsche, I. (2005) "Jak rozumět a konkurovat mužům na pracovišti" (How to understand and compete with men in the workplace), Grada Publishing, Praha, Czech Republic, 2005. (in Czech)

Olšovská, A., Mura, L., Švec, M. (2016) "Personnel Management in Slovakia: An Explanation of the Latent Issues", Polish Journal of Management Studies, 13(2), pp. 110-120.

Osabiya, B. J. (2015) "The effect employees' motivation on organizational performance", Journal of Public Administration and Policy Research, 7(4), pp. 62-75. https://doi.org/10.5897/JPAPR2014.0300

Poór, J., Engle, A. D., Blštáková, J., Joniaková, Z. (2018) "Internationalisation of Human Resource Management: Focus on Central and Eastern Europe", Nova Science Publishers, New York, NY, USA.

Richman, N. (2015) "Human resource management and human resource development: Evolution and contributions", Creighton Journal of Interdisciplinary Leadership, 1(2), pp. 120-129. https://doi.org/10.17062:CJIL.vli2.19

Robescu, O., Iancu, A. G. (2016) "The Effects of Motivation on Employees Performance in Organizations", Valahian Journal of Economic Studies, 7(21), pp. 49-56. https://doi.org/10.1515/vjes-2016-0006

Sánchez-Sellero, M. C., Sánchez-Sellero, P., Cruz-González, M. M., Sánchez-Sellero, F. J. (2018) "Determinants of Job Satisfaction in the Spanish Wood and Paper Industries: A Comparative Study Across Spain", Drvna Industrija, 69(1), pp. 71-80. https://doi.org/10.5552/drind.2018.1711

Sánchez-Sellero, M. C., Sánchez-Sellero, P., Cruz-González, M. M., Sánchez-Sellero, F. J. (2013) "Stability and Satisfaction at Work During the Spanish Economic Crisis", Prague Economic Papers, 26(1), pp. 72-89. https://doi.org/10.18267/j.pep.596

Schmidtová, J., Vacek., V. (2013) "Applied Statistics", Technical University in Zvolen, Zvolen, Slovakia.

Smith, D. (2012) "Guanxi, Mianzi, and Business: The Impact of Culture on Corporate Governance in China", Private Sector Opinion, 26, World Bank, Washington, DC, USA, pp. 1-16. [online] Available at: https://openknowledge.worldbank.org/bitstream/ handle/10986/17094/726920BRI00PUB0OWLEDGE0NOTESOSERIES.pdf? sequence $=1 \&$ isAllowed=y [Accessed: 10 July 2018]

Stachová, K., Papula, J., Stacho, Z., Kohnová, L. (2019) "External Partnerships in Employee Education and Development as the Key to Facing Industry 4.0 Challenges", Sustainability, 11(12), Article number: 345 .

https://doi.org/10.3390/su11020345

Stachová, K., Stacho, Z., Blštáková, J., Hlatká, M., Kapustina, L. M. (2018) "Motivation of Employees for Creativity as a Form of Support to Manage Innovation Processes in TransportationLogistics Companies", Naše More, 65(4), pp. 180-186. https://doi.org/10.17818/NM/2018/4SI.3
Stachová, K., Stacho, Z., Vicen, V. (2017) "Efficient involvement of human resources in innovations through effective communication", Business: Theory and Practice, 18, pp. 33-42. https://doi.org/10.3846/btp.2017.004

Statistic How To (2018) "ANOVA Test: Definition, Types, Examples", [online] Available at: https://www.statisticshowto.com/probability-and-statistics/hypothesis-testing/anova/ [Accessed: 22 May 2018]

Statistic Solutions (2013) "ANOVA", [online] Available at: https://www. statisticssolutions.com/manova-analysis-anova/ [Accessed: 22 April 2018]

Šustr, M., Pluhař, M. J., Soušek, R., Fuchs, P., Nedeliaková, E. (2016) "Methodologies for the crisis states in the Czech Republic", In: Proceedings of The 20th World Multi-Conference on Systemics, Cybernetics and Informatics (WMSCI 2016), pp. 242-246. [online] Available at: https://www.iiis.org/CDs2016/CD2016Summer/ papers/RA551XU.pdf [Accessed: 24 April 2017]

Tokarčíková, E., Kucharčíková, A. (2015) "Diffusion of innovation: the case of the Slovak mobile communication market", International Journal of Innovation and Learning (IJIL), 17(3), pp. 359-370. https://doi.org/10.1504/IJIL.2015.068467

Vetráková, M., Ďurian, J., Seková, M., Kaščáková, A. (2016) "Employee Retention and Development in Pulp and Paper Companies", BioResources, 11(4), pp. 9231-9243. https://doi.org/10.15376/biores.11.4.9231-9243

Xing, Y., Zhang, L., Liu, Z., Wilde, J. T., Chen, H., Zhang, L. (2017) "The Impact of Cultural Differences on Chinese Commercial Activity in Europe", Carnegie-Tsinghua Center of Global Policy, Beijing, China. [online] Available at: https://carnegietsinghua. org/2017/05/24/impact-of-cultural-differences-on-chinese-commercial-activity-in-europe-event-5598 [Accessed: 24 July 2017]

Zaborova, E. N., Glazkova, I. G., Markova, T. L. (2017) "Дистанционное Обучение: Мнение Студентов" (Distance learning: Students' perspective), Sotsiologicheskie Issledovaniya, 2, pp. 131-139. [online] Available at: https://socis.isras.ru/index. php?page_id $=508 \& \mathrm{id}=6566 \& \mathrm{param}=$ https://socis.isras.ru/files $/$ File/2017/2017_2/Zaborova.pdf[Accessed: 21 July 2018] (in Russian)

Zafar, N., Ishaq, S., Shoukat, S., Rizwan, M. (2014) "Determinants of Employee Motivation and its impact on Knowledge Transfer and Job Satisfaction", International Journal of Human Resource Studies, 4(3), pp. 50-69. https://doi.org/10.5296/ijhrs.v4i3.5874

Žulová, J., Švec, M., Madleňák, A. (2018) "Personality aspects of the employee and their exploration from the GDPR perspective", Central European Journal of Labour Law and Personnel Management, 1(1), pp. 68-77. https://doi.org/10.33382/cejllpm.2018.01.05 